Konferencja naukowa pod patronatem Ministra Zdrowia

Promocja zdrowia podstawą zdrowia publicznego. Promocja zdrowia dla osób starszych

Narodowy Instytut Zdrowia Publicznego - Państwowy Zakład Higieny w Warszawie

Warszawa, dnia 8 września 2017 r.

\title{
Dyskusja panelowa: Kierunki zmian w ustawie o zulowiu publicznym w celu wzmocnienia promocji zulrowia
}

\section{Wprowadzenie}

Ustawa o zdrowiu publicznym uchwalona 18 listopada 2015 roku jest w Polsce niewątpliwie znaczącym (jeśli nie zasadniczym) krokiem jego nowoczesnego ukierunkowania, w którym wydobywa się i wspiera działania na rzecz zdrowia populacji; nie tylko zapewnienia bezpieczeństwa, ale i tworzenia warunków zdrowego życia na każdym etapie życia ludzi, w różnych miejscach i bez względu na posiadane zasoby indywidualne. W zapisach ustawy przyjęto, że Narodowy Program Zdrowia (NPZ) jest drogowskazem tych działań. Wskazano instytucje publiczne (rządowe i samorządowe), które w zakresie swych kompetencji powinny to robić i nawet określono niezbędne środki, chociaż skromne.

Polska ustawa, wymieniając promocję zdrowia, nie rozwija jednak tej działalności jako podstawy nowoczesnego zdrowia publicznego. Mimo że minęło już 30 lat od Karty Ottawskiej, to w polskich działaniach na rzecz promocji zdrowia za mało jest profesjonalizmu, chociaż podejmowane są liczne inicjatywy (szczególnie przez NGOsy oraz media), brakuje badań, które potwierdzałyby efektywność interwencji i programów zdrowotnych, ograniczone są zasoby kadrowe i fundusze. $\mathrm{Z}$ tego powodu ustawa o zdrowiu publicznym wymagałaby nowelizacji, uwzględniającej promocję zdrowia albo, wzorem niektórych krajów europejskich, przygotowania projektu specjalnej ustawy, obejmującej promocję zdrowia i prewencję pierwotną. Powstaje więc pytanie, w jakim zatem kierunku powinny zmierzać nowe czy zmodyfikowane regulacje w zakresie zdrowia publicznego, aby:

- uwzględniać to, że polityka zdrowotna ukierunkowana na inwestowanie $\mathrm{w}$ zdrowie dokonuje się we wszystkich politykach - nie jest to wyłącznie odpowiedzialność sektora zdrowotnego i ministra zdrowia; - uwzględniać to, że działania promocji zdrowia powinny być adresowane do wszystkich - na każdym etapie życia ludzi, zarówno młodych, jak i starszych oraz całkiem sędziwych i we wszystkich miejscach ich przebywania (settings); w rodzinach, szkołach, w zakładach pracy i domach opieki;

- uwzględniać to, że spektrum efektywnych działań promocji zdrowia obejmuje nie tylko ograniczanie głównego ryzyka zdrowotnego - palenia tytoniu i nadmiernego picia alkoholu (chociaż to bardzo ważne!), lecz także rozwijanie działań sprzyjających zdrowiu: aktywności fizycznej, zdrowego żywienia, integrujących relacji i aktywności społecznych oraz tworzenia wyrównanych zdrowotnie warunków życia, obejmujących tak środowisko naturalne, jak i warunki bytu.

MIROSŁAW WYSOCKI: Rozpoczynamy dyskusję panelową na temat pożądanych kierunków zmian w ustawie o zdrowiu publicznym w celu wzmocnienia promocji zdrowia, w której uczestniczą: Dorota Cianciara, Zbigniew Król, Beata Małecka-Libera, Zofia Słońska, Tomasz Zdrojewski i Małgorzata Zwiercan. Cieszę się z obecności Pani Małgorzaty Zwiercan, przewodniczącej Komisji Senioralnej Sejmu, ze względu na prośbę o poinformowanie Komisji o tym, że taka konferencja, która dotyczy przede wszystkim seniorów, odbyła się w naszym Instytucie.

Dwa lata temu Sejm uchwalił ustawę o zdrowiu publicznym, która potem bardzo szybko została podpisana przez prezydenta. Miałem zaszczyt i Pan prof. Tomasz Zdrojewski również, być w zespole, którym kierowała Pani minister Beata Małecka-Libera i w ciągu pięciu tygodni przygotowaliśmy niezłą ustawę, która potem (ja to powtarzam kolejny raz) została w kilku elementach niekorzystnie zmieniona (,zmasakrowana”), i to nie w Komisji Sejmowej, nie w parlamencie, tylko w rządzie; nie w tym, lecz w poprzednim. Dlatego też ta ustawa nie wygląda tak dobrze, jak wyglądała na początku. Być może, stąd wynika potrzeba zastanowienia się nad koniecznością korekt czy dopisania przepisów wykonawczych. Fakt, że ta ustawa istnieje i w jakimś zakresie funkcjonuje, jest już sukcesem. Trzeba także zauważyć, że były głosy dość mocno krytykujące tę ustawę. Na przykład był taki duży wykład prof. Huberta Izdebskiego, wytykający różne niedostatki, które zresztą wynikały nie z tego, co napisaliśmy, tylko z późniejszej działalności rządu. Proszę o wypowiedź Panią poseł, która była główną autorką tej ustawy.

BEATA MAŁECKA-LIBERA: Będę mimo wszystko broniła tej ustawy, mając świadomość, że nie jest doskonała, jak większość ustaw; żadna nie jest idealna. Ustawa 
powinna być nowelizowana nie wtedy, kiedy wchodzi w życie, lecz wtedy, kiedy jest realizowana. W trakcie realizacji wychodzi wiele różnych doświadczeń, zaniechań i wtedy warto wracać i poprawiać prawo. To, co powiedział prof. Mirosław Wysocki, niezupełnie jest precyzyjne. Pięć tygodni trwało samo pisanie ustawy, natomiast debata nad ustawą, niezliczona liczba wersji założeń, projektów, to w sumie 10 lat pracy wszystkich osób związanych z edukacją, ze zdrowiem publicznym, a także pracy dużego grona osób, które pilotowały tę ustawę w Sejmie. To był bardzo trudny proces. Przez wiele lat na różnych konferencjach mówiliśmy o potrzebie stworzenia fundamentów zdrowia publicznego i uchwalenia ustawy. W rzeczywistości było to ogromnie trudne wyzwanie, żeby szybko do takiego momentu doszło. Dlatego nie zgodzę się z twierdzeniem, że ustawa została przygotowana w ciągu pięciu tygodni. W tym czasie złożone zostały wszystkie założenia i teksty, które przygotowaliśmy w ciągu poprzednich lat. Natomiast cały proces powstania od momentu złożenia przez Ministerstwo Zdrowia do rządu, a później do parlamentu, przebiegał rzeczywiście dość szybko, ponieważ wiązało się to z presją czasu; co miało związek z upływem kadencji Sejmu. Mieliśmy wybór i wszyscy, którzy braliśmy udział w powstawaniu tej ustawy, zgodziliśmy się, że jeżeli tego teraz nie zrobimy, to w ciągu następnych lat tej ustawy nie będzie.

Jestem świadoma, że nie jest to idealna ustawa, ale daje możliwości tworzenia różnych rzeczy w jej ramach, daje również możliwość rozwinięcia tematu promocji zdrowia, bo w ustawie o zdrowiu publicznym tylko się promocję zdrowia wymienia, ale rozwija w NPZ.

Ustawa celowo nie jest szczegółowa. Zapisy są ujęte ogólnie, sugerująco, ale dają możliwość rozwoju w różnych kierunkach. To był nasz wybór. Na sali obecne są dwie osoby z zespołu przygotowującego tekst ustawy. Ja nie pisałam tej ustawy sama, nie pisałam tej ustawy z urzędnikami, z prawnikami, ale właśnie z ekspertami zdrowia publicznego. I uważaliśmy, że tu nie chodzi o to, żeby na setkach stron zapisać szczegółowe rozwiązania, które później nie będą realizowane. Chodziło o stworzenie podstaw, stworzenie fundamentów i uważam, że to się udało.

Nie udało się jednak, i to jest fakt, wyżej ulokować instytucji odpowiedzialnej za realizację ustawy. Początkowo proponowaliśmy obligatoryjnie umocować pełnomocnika do spraw zdrowia publicznego bardzo wysoko, czyli w Kancelarii Premiera. Do tej pory uważamy, że takie stanowisko jest potrzebne. To wszystko, co tutaj było powiedziane o promocji zdrowia, jest absolutnie możliwe do zrealizowania w zakresie tejże ustawy poprzez działania pełnomocnika, który koordynowałby działania w sferze zdrowia publicznego.

Wczoraj, podczas spotkania na Forum Ekonomicznym w Krynicy, rozmawiałam z Panem ministrem na temat zdrowia publicznego. Oboje byliśmy absolutnie zgodni, że za działania w dziedzinie zdrowia publicznego odpowiedzialny jest nie tylko minister zdrowia, a tym bardziej wiceminister do spraw zdrowia publicznego, który jest w randze podsekretarza stanu. Nie jest upoważniony do prowadzenia rozmów z innymi ministerstwami, a przecież kluczową sprawą jest to, aby zainteresować zdrowiem publicznym i wdrożyć do pracy również inne ministerstwa. Po dwóch latach działania tej ustawy mogę powiedzieć jedno: to nie jest zła ustawa. Możemy oczywiście dyskutować tutaj, czy najważniejszą sprawą jest jej nowelizacja, ale moim zdaniem najważniejsze to zacząć ją realizować.

Co do NPZ nie zgodzę się tutaj z wypowiedzią, że istnieje nierówność w traktowaniu celów operacyjnych, jako że ich opisy mają różną objętość stron. To nie chodzi o opis, to nie chodzi o uzasadnienie, rzecz nie w liczbie stron. Chodziło nam o to, żeby NPZ zawierał te cele, które zdaniem ekspertów zdrowia publicznego są najważniejsze. Jak państwo na pewno zauważyliście, NPZ obecnie nie jest oparty na jednostkach chorobowych (jak było w poprzednim NPZ), tylko na wyzwaniach, jakimi są otyłość, uzależnienia, zaburzenia zdrowia psychicznego czy też właśnie wyzwanie demograficzne, na które bardzo mocno i jasno w tym narodowym programie zwrócono uwagę. Tu chodzi o fakt, że te wszystkie cele, jednakowo ważne, jednakowo istotne dla zdrowia publicznego, dostrzegliśmy i uważamy, że powinny być kontynuowane przez następne lata.

I jeszcze jedna rzecz, do której chciałabym się odnieść, mianowicie Pani prof. Dorota Cianciara powiedziała, że państwo najbardziej oczekujecie od takiej ustawy, aby zawierała zapisy o działaniach instytutów, kierunkach badań naukowych, kształceniu kadr, funduszach itd. Uważam, że to wszystko może być realizowane poprzez obecne zapisy tej ustawy. Pełnomocnik do spraw zdrowia publicznego mógłby korzystać z pracy tych wszystkich instytutów, które mamy. Największą naszą bolączką jest niewątpliwie niedostateczna liczba badań epidemiologicznych. To bardzo mocno podkreślaliśmy w trakcie uzasadnienia do ustawy o zdrowiu publicznym, jak również mówiliśmy o potrzebie wykorzystania kadr, jakimi są absolwenci zdrowia publicznego. W moim odczuciu należy ustawę tylko dobrze odczytać i konsekwentnie realizować. To oczywiście nie gwarantuje tego, że za kilka lat nie trzeba będzie jej rozszerzać i nowelizować. Proszę mi wierzyć, mam trochę doświadczenia politycznego i wiem, że jeżeli teraz otworzymy ustawę, to mogą różne rzeczy zadziałać. Ona będzie nowelizowana, znowu minie rok, dwa i kompletnie nic dalej się nie będzie działo. Więc raczej bym zachęcała: małymi krokami do realizacji, a wnioski zostawmy sobie na czas późniejszy. Dziękuję.

MIROSŁAW WYSOCKI: Bardzo Pani dziękuję. Też raczej jestem zdania, żeby uzupełniać i poprawiać tę ustawę przez rozporządzenia i zarządzenia wykonawcze. To była olbrzymia zasługa Pani jako sekretarza stanu (ja ciągle powracam do tych pięciu tygodni, bo oczywiście doświadczenia były zbierane długo, ale robiliśmy to w pięć tygodni). Pamiętam taki moment: już byliśmy na finiszu i przyszło takich dwóch smutnych panów, jak się okazało, byli z Departamentu Prawnego Ministerstwa i powiedzieli, że w ogóle to jest niemożliwe, więc po tym z Panem prof. Tomaszem Zdrojewskim wyszliśmy, a Pani Minister została i nie wiem, jak Pani to zrobiła, ale Pani ich przekonała, że to jest możliwe. 
Chciałem dodać kilka dobrych słów o NPZ. Poprzedni NPZ adresował zadania do wszystkich, czyli de facto do nikogo, i nie miał finansowania, więc minister wybierał to, na co znajdował środki: przeciwdziałanie alkoholizmowi, ograniczenie palenia tytoniu i właściwie... na nic więcej. Natomiast obecny NPZ wskazuje sześć głównych problemów zdrowotnych (być może można by nieco inaczej dobrać tematy główne czy cele) i ma środki finansowe na realizację. Myślę, że to jest początek finansowania. Nie wierzę, że premier Mateusz Morawiecki w przyszłym roku chciałby zmniejszyć finansowanie.

DOROTA CIANCIARA: Doceniam stanowisko Pani poseł i pozostałych autorów ustawy. Rozumiem też, że proces legislacyjny to jest długa, żmudna, a czasem mało owocna droga. W związku z tym metoda małych kroków bardzo mi odpowiada. Osobiście, gdybym miała mieć wpływ na kształt tej ustawy, to upierałabym się przy dwóch sprawach.

Po pierwsze, zależałoby mi na tym, żeby zdefiniować tam przynajmniej podstawowe pojęcia, ponieważ czytelnik nie ma pewności, czy ustawa o zdrowiu publicznym jest ustawą o zdrowiu publiczności czy o nauce i sztuce poprawy stanu zdrowia populacji. Bardzo zależałoby mi na tym, abyśmy znaleźli jakąś, choćby niedoskonałą, ale uzgodnioną definicję promocji zdrowia.

Po drugie, chciałabym też zwrócić uwagę na kwestię, która już się tu pojawiła, to jest na instytucjonalizację. Otóż mamy w tej chwili taką sytuację, że na poziomie centralnym zaprojektowano pewne ciała. Mamy Radę do spraw Zdrowia Publicznego, Komitet Sterujący NPZ, mówimy o Urzędzie Zdrowia Publicznego, mówimy o instytutach. W skrócie mówimy o pewnej czapce, o czubku piramidy. Natomiast prawda jest taka, że promocję zdrowia będą prowadzić samorządy, jednostki samorządu terytorialnego. Tu chciałabym Państwu zacytować króciutkie trzy opinie z badań fokusowych, które przeprowadziliśmy w Narodowym Instytucie Zdrowia Publicznego - Państwowym Zakładzie Higieny (NIZP-PZH) wśród pracowników samorządów. Myślę, że one są bardzo znaczące i polecam je Państwa uwadze:

- Ale tak naprawde zadania sa w starostwach, nie wiem, czy Pani potwierdza, tak wyśrubowane i tak jest dużo zadań do realizacji, że blędem jest to, że narzuca się na jednostki samorzadu terytorialnego realizację czegoś, a tak naprawdę nie ma ludzi do realizacji, do koordynowania.

- Wyszło jeszcze wiele innych jednostek chorobowych, które wyszły jakby przy okazji... My nie mogliśmy przewidzieć, że $w$ programie wyłapiemy trójkę dzieci śmiertelnie chorych, tak? Nam chodziło o stwierdzenie skali zjawiska.

- Bo my opracowaliśmy kilka programów i to jest robota potad $i$ nikt nie chce się zajmować opracowaniem. To, ze samorzady miaty same opracowywać i moja koleżanka po politechnice, my razem działałyśmy, to jest nieporozumienie.

Otóż sądzę, że tak długo, jak nie skonstruujemy prawdziwie systemowego wsparcia dla jednostek samorządu terytorialnego (JST), nie uda się nam oddolna realizacja programów promocji zdrowia i zdrowia publicznego. To, że ustawa, a w ślad za nią rozporządzenie, dają fantastyczną ścieżkę wsparcia finansowego dla samorządów poprzez NFZ, to jest strzał w dziesiątkę. Niemniej, w moim odczuciu, to jest jeszcze za mało. Samorządy są za słabe merytorycznie, one naprawdę potrzebują wsparcia. Czy to wsparcie miałoby polegać na tym, że tam będzie miejsce pracy dla promotora zdrowia? To byłoby jedno z rozwiązań. Drugim jest to, że możemy stworzyć system szkoleń, system konsultacji przy tworzeniu programów polityki zdrowotnej. Możemy mówić o tym, jak to zorganizować, ale jestem całkowicie przekonana, że bez wsparcia samorządów nie ruszymy z realizacją NPZ.

MIROSŁAW WYSOCKI: Sadzę, że gdy mówimy o samorządach, to powinniśmy uwzględnić funkcje koordynatorów do spraw zdrowia publicznego na szczeblu wojewódzkim i powiatowym. Powinny to być miejsca pracy dla absolwentów wydziałów nauk o zdrowiu. Tych ludzi, którzy dużo wiedzą o zdrowiu publicznym, a nie miejsca dla czyichś krewnych: ciotek, wujków czy zięciów.

Chciałem prosić Pana ministra Zbigniewa Króla, który wczoraj uczestniczył w podobnej dyskusji, aby jeszcze raz przedstawił swoją opinię o ustawie oraz o roli Rady do spraw Zdrowia Publicznego. Chciałbym jeszcze wrócić do White Paper - dokumentu, który powstał trzy lata temu, w którym zespół ekspertów NIZP-PZH we współpracy z zespołem dyrektora Michała Kępowicza z Ministerstwa Zdrowia wykonał pierwsze mapy potrzeb zdrowotnych. Prof. Marian Zembala jako minister zdrowia pojechał z tym do Brukseli i dostał 12 mld złotych przeznaczonych w pewnej części (w znacznej!) właśnie na działania samorządów w tej dziedzinie, o której mówimy. Czy możemy, Panie ministrze, coś na ten temat usłyszeć?

ZBIGNIEW KRÓL: Na początku chciałbym Państwa przywitać. Dziękuję Pani prof. Stanisławie Golinowskiej, dziękuję władzom UJ i oczywiście dyrekcji NIZP za zorganizowanie tej konferencji.

Jeśli chodzi o ocenę ustawy, to ja nie będę jej krytykował. Po dwudziestu paru latach od momentu powstania Szkoły Zdrowia Publicznego w Krakowie mamy już pełną świadomość, że ustawę powinniśmy wszyscy realizować, a także usiłować jej bronić i znajdować w niej miejsca, w które można ewentualnie „wkładać” pomysły związane z promocją zdrowia. Powinny być one realizowane, na przykład te związane z aktywnością fizyczną. Wszyscy akceptujemy tezę, że aktywność fizyczna powinna być wdrażana. Ale czy indywidualnie robimy to także? Pytanie: Czy Państwo szli po schodach? Tak? Ale czy tylko dlatego, że przy windzie była długa kolejka? To jest jedna z tych rzeczy, które można łatwo odnieść do siebie, i taka świadomość może być krzewiona wszędzie, gdzie to możliwe, niezależnie od miejsc, które zajmujemy.

„Będąc młodym lekarzem”, nie myślałem w ogóle o czymś takim jak promocja czy profilaktyka. Byłem 
kształcony na wysokospecjalistycznych procedurach. Z kolei będąc młodym urzędnikiem, uważałem, że możemy wszystko pozmieniać, jeśli tylko mamy środki. Będąc młodym politykiem, bardzo chciałbym się opierać na konkretnych działaniach - dobrych praktykach. Wiele z tych działań można wdrażać w zakresie zdrowia publicznego.

Czy do tego potrzebujemy nowych aktów prawnych, czy raczej instytucji, które by te działania wspierały? Moje doświadczenie - i myślę, że większości z Państwa - również dowodzi, że powołanie nowych aktów prawnych do rozwiązywania spraw oczywistych nie zawsze jest środkiem pierwszej wagi. Pewnie część z Państwa też pamięta taką ustawę systemową, która zapisuje prawo do ochrony zdrowia w Polsce. Zdrowie publiczne było w niej zdecydowanie lepiej zdefiniowane niż teraz, ale nie przyspieszyło zmian. Dlatego uważam, że powinniśmy definiować promocję zdrowia, ale niekoniecznie potrzebujemy do tego nowych aktów prawnych.

W jeden z celów NPZ wpisana jest promocja zdrowego starzenia się. Jak rozpoznawać potrzeby osób w starszym wieku? Dzięki różnego rodzaju badaniom mamy takie poczucie, że znamy potrzeby osób w starszym wieku. Ale musimy pamiętać, że z perspektywy medycznej to są inne potrzeby niż z perspektywy pomocy społecznej. To są dwa różne elementy oceny; inne. Często nie spotykają się z realnymi potrzebami danej osoby. Pani prof. Stanisława Golinowska przedstawiła przyjęte w statystyce fazy starzenia się, ale pamiętajmy, że nie zawsze wiek metrykalny odpowiada wiekowi biologicznemu.

$\mathrm{W}$ polskich warunkach rodzimy się oraz umieramy w większości w placówkach medycznych. Jeżeli cokolwiek dzieje się starszej osobie, to praktycznie jest zaraz przewożona do szpitala, gdzie lekarze reagują zgodnie z procedurami. Nie odnoszą się do wieku biologicznego. Tymczasem powinniśmy robić badania, aby umieć rozpoznać realne potrzeby takich pacjentów, tym bardziej że patrząc na fazy starzenia się, ostatni okres charakteryzuje się dużym prawdopodobieństwem tego, że to wtedy potrzebnych jest najwięcej interwencji medycznych - oczywiście zgodnie z wiekiem biologicznym, a nie metrykalnym.

Promocja zdrowia w zasadzie nie przynosi szkód. Jednak jeżeli mówimy o profilaktyce poważnie, to powinniśmy dostrzegać, że to jest normalna technologia medyczna, która kosztuje i może przynieść korzyści. Posłużę się tutaj przykładem badań przesiewowych dotyczących zapamiętywania. Jedna z dużych instytucji w Polsce robiła badania zapamiętywania - chodziło o wykrycie wczesnej demencji. Trudno jednak oszacować, na ile takie badania są skuteczne, czy osoba w wieku 55 lat powinna już mieć to badanie zrobione, czyli jeszcze w wieku aktywności zawodowej, kiedy nie jest jeszcze formalnym adresatem takich badań.

Należy podkreślić też, jak ważne jest dotarcie $\mathrm{z}$ informacją do ludzi starszych. Podejrzewam, że w ogóle nie mamy dostatecznej liczby badań na ten temat. Nie mamy też projektów konstruowania takiego systemu docierania do informacji i z informacją do osób starszych. Ważny jest dostęp do odpowiednich danych informatycznych.
Padły wcześniej opinie o braku w samorządach potencjału do tego, żeby aktywnie tworzyć programy promocji zdrowia. Proszę pamiętać, że samorządy otrzymały to zadanie wraz z pierwszą ustawą o samorządach gminnych, jeszcze wcześniej niż uchwalono ustawę o ZOZ-ach, chyba w 1991 roku. Reforma administracyjna z roku 1999 również wskazała na samorządy każdego szczebla jako zobowiązane do działań z zakresu promocji zdrowia i profilaktyki.

Z kolei dzięki ustawie o Agencji Oceny Technologii Medycznych programy zdrowia publicznego i profilaktyki zdrowotnej, przygotowywane przez samorządy terytorialne, mają wsparcie w ocenie i selekcji, aby były trafne i mogły być jak najlepiej wykorzystane dla osób starszych.

Podnoszenie problemu, że samorządy nie są przygotowane do działań z zakresu promocji zdrowia, jest dowodem na to, że nie chodzi tu o regulacje prawne, bo tych raczej nie brakuje.

MIROSŁAW WYSOCKI: Bardzo dziękuję Panu ministrowi za te ważne uwagi. Pan mówił o interwencjach u osób starszych. Prof. Bogdan Wojtyniak i doktor Paweł Goryński prowadzą w tym instytucie ogólnopolskie badania chorobowości szpitalnej. Ponad $7 \mathrm{mln}$ hospitalizowanych rocznie. Szacujemy, że $12-15 \%$ tych hospitalizacji, zwłaszcza dla osób starszych, jest niepotrzebnych, a przy tym mogą być czynnikiem pogarszającym stan zdrowia starszych pacjentów. Ograniczenie niepotrzebnych hospitalizacji tworzy pole do oszczędności. Zaoszczędzone tak pieniądze należy przeznaczyć na dobrą opiekę domową i na opiekę społeczną - tak, że to się będzie wyrównywać. I teraz pytanie do Pani przewodniczącej Małgorzaty Zwiercan: Jak Pani widzi w kontekście tego, co zostało do tej pory powiedziane, sprawę promocji zdrowia przeznaczonej dla osób starszych? Czy Komisja Senioralna o tym rozmawia?

MAŁGORZATA ZWIERCAN: Na wszystkich posiedzeniach Komisji Polityki Senioralnej w Sejmie rozmawiamy o osobach starszych - taka jest rola tej komisji. Wyciągamy wnioski z danych i raportów, a nasi stali eksperci przygotowują dezyderaty przesyłane do Ministerstwa Zdrowia i do Ministerstwa Rodziny, Pracy i Polityki Społecznej. Jeżeli chodzi o ustawę, o której tutaj dzisiaj mówimy, uważam, że bardzo dobrze, że ta ustawa powstała. Smuci mnie tylko, że została, tak jak powiedział Pan prof. Mirosław Wysocki, zmasakrowana. Nie widziałam pracy przygotowanej wcześniej i myślę, że warto by było do tych materiałów może zerknąć, żeby popracować nad nowelizacją. Ważne, że ta ustawa jest, i to tylko od nas będzie zależało, jak ona będzie wykorzystana.

Pani prof. Stanisława Golinowska przedstawiła bardzo ważny slajd, któremu pozwoliłam sobie zrobić zdjęcie. Powiedziała, że wiek 50-67 obejmuje starszych pracowników, jeszcze zawodowo aktywnych. Wiek 67 $80 / 85$ to tak zwany trzeci wiek, w przeważającym stopniu już na emeryturze. To na ogół osoby aktywne społecznie i rodzinnie. Wiek 80-85+, czyli tak zwany czwarty wiek, 
to okres stopniowo coraz większej zależności, wymagający opieki. Ja myślę, że wczesna profilaktyka to jest takie nasze marzenie i mam nadzieję, że ono się spełni, ale to wszystko zależy od nas i od tego, jak ta profilaktyka będzie stosowana. Nie tylko profilaktyka, ale też aktywizacja osób starszych, uczenie Polaków życia w zdrowiu od najmłodszych lat. Jeżeli wcześnie zaczniemy stosować profilaktykę, prowadzić programy promocji zdrowia już wśród dzieci w szkołach, to będziemy dłużej zdrowsi.

Nie prowadzimy edukacji zdrowotnej, a powinniśmy to robić. Dużo tańsza jest profilaktyka niż leczenie osób w podeszłym wieku. Dlatego uważam, że to dobrze, że znamy kierunek zmian, ale jak efektywnie będziemy wykorzystywać to, co mamy, to zależy przede wszystkim od nas.

MIROSŁAW WYSOCKI: Wracam do Forum Ekonomicznego w Krynicy. Przypominaliśmy sobie na nim o takim dniu w 2007 roku, kiedy wszystkie kraje członkowskie UE podpisały dyrektywę Zdrowie we wszystkich politykach. „W imieniu rządu” podpisywał to minister Marek Twardowski, ja też tam byłem, bo akurat wtedy jeździłem na spotkania Komisji Europejskiej. W wielu krajach dyrektywa jest realizowana. Wczoraj w Krynicy była minister z Danii. W niezwykle światły sposób opisywała to, co się u nich we wszystkich resortach dzieje. To jest rzeczywiście zdrowie we wszystkich politykach, we wszystkich resortach. Natomiast my nie możemy się nadal doprosić wprowadzenia jednej godziny tygodniowo na temat zdrowia w szkole w programach szkolnych. Warto, żebyśmy o tym myśleli. Proszę teraz o zabranie głosu Panią dr Zofię Słońską, której background to ten instytut. Ona wyszła z PZH, potem poszła do Instytutu Kardiologii, ale nadal zachowała umiejętność wyłapywania takich rzeczy, które można dosyć łatwo poprawić w całym zdrowiu publicznym.

ZOFIA SŁOŃSKA: Na początek chciałam nawiązać do poruszonej przez Panią prof. Dorotę Cianciarę kwestii problemów komunikacyjnych, występujących w Polsce w środowisku profesjonalistów zajmujących się zdrowiem publicznym, a wynikających z różnej interpretacji pojęć z zakresu zdrowia publicznego. W marcu bieżącego roku odbyła się w Senacie RP konferencja poświęcona NPZ na lata 2016-2020, w trakcie której został zgłoszony i przyjęty przez uczestników konferencji z aprobatą postulat organizacji zespołu ekspertów do spraw ujednolicenia interpretacji podstawowych pojęć funkcjonujących $\mathrm{w}$ zdrowiu publicznym, a w tym w promocji zdrowia. Podjęcie działań zmierzających do realizacji tej inicjatywy wydaje mi się bardzo użyteczne.

Druga kwestia, do której pragnę się odnieść, to konieczność wspierania rozwoju współpracy interdyscyplinarnej w ramach promocji zdrowia. Partnerska współpraca interdyscyplinarna $\mathrm{w}$ naszym kraju nie ma zbyt bogatych tradycji, $w$ tym również $w$ odniesieniu do medycyny i nauk społecznych. W przypadku promocji zdrowia, także osób starszych, których wspieranie wymaga oddziaływania na systemy i instytucje społeczne, potrzebna jest intensyfikacja $\mathrm{i}$ instytucjonalizacja rutynowej współpracy między przedstawicielami nauk społecznych i sektora zdrowia w celu przyczynienia się do podejmowania optymalnych decyzji w wielu sferach istotnych dla zdrowia. W obecnej sytuacji instytucje, zajmujące się często tymi sami problemami, nie współpracują wystarczająco ze sobą, a tym samym nie wykorzystują własnej wiedzy i doświadczenia, tak jak byłoby to możliwe.

Czasem jako negatywne zjawisko postrzega się podejmowane przez pozamedyczne dziedziny próby interpretowania promocji zdrowia, jej założeń, sposobów diagnozowania, przyjętych celów oraz obszarów działania, w kategoriach obowiązujących we własnej dyscyplinie. Jeśli tego rodzaju działania są poprawne, nie prowadzą do przekłamań, to tylko powód do radości z tego, że są podejmowane. Promocja zdrowia z założenia musi być dziedziną interdyscyplinarną i jej monopolizowanie nie służy jej samej. Co przemawia za interdyscyplinarnością promocji zdrowia? Cel, w imię którego powstała, to jest upowszechnienie prozdrowotnych stylów życia poprzez oddziaływanie na ich różnorodne uwarunkowania. Wiele uwarunkowań tworzących otoczenie materialne i społeczne zachowań związanych ze zdrowiem oglądaliśmy w demonstrowanym wcześniej wachlarzu uwarunkowań zdrowia.

Ponadto style życia to nie kategoria medyczna, tylko społeczna, na dodatek składająca się z czynników odpowiadających za ponad 50\% zmienności w stanie zdrowia. Stylu życia nie da się zmienić jedynie poprzez przekazywanie informacji o normach zachowań i ostrzeganie, że należy się zdrowo zachowywać, bo inaczej się zachoruje. Kształtowanie zachowań prozdrowotnych wymaga działania w wielu dziedzinach życia z udziałem interdyscyplinarnych zespołów oraz współpracujących z sobą sektorów społecznych, zarówno rządowych, jak i pozarządowych.

Swoją przygodę $\mathrm{z}$ promocją zdrowia rozpoczęłam już prawie 30 lat temu, zaczynając od pracy w Biurze Europejskim WHO jako konsultant do spraw promocji zdrowia. Potem przez ponad 10 lat wykonywałam prace wynikające $z$ mojej funkcji jako krajowego partnera WHO do spraw promocji zdrowia. Zarówno sprawowane funkcje, jak i nieprzerwana praca badawcza pozwoliły mi na wnikliwą obserwację rozwoju promocji zdrowia w naszym kraju. Doszłam do wniosku, że idea promocji zdrowia z całym swoim oprzyrządowaniem, a przede wszystkim ze sposobem podejścia do rozwiązywania współczesnych problemów, zasługuje na miano strategii, która nadaje się do wykorzystania jako krajowa strategia rozwiązywania współczesnych problemów zdrowotnych. Niestety, w praktyce promocja zdrowia, często nie do końca dobrze rozumiana, bywa utożsamiana $\mathrm{z}$ edukacją zdrowotną i traktowana jako bliżej nieokreślony dodatek do działań klinicznych.

Pozycja promocji zdrowia w systemie ochrony zdrowia, podobnie jak pozycja całego zdrowia publicznego, musi być stale wzmacniana. Stąd bardzo ważna rola ustawy o zdrowiu publicznym, a także NPZ. Potrzebny jest rzeczywisty, a nie deklarowany, udział wszystkich sektorów na rzecz tworzenia prozdrowotnych środowisk budujących warunki do rozwoju zdrowia, między innymi także dlatego, żeby uniemożliwiały bądź znacząco 
ograniczały pojawianie się behawioralnych czynników ryzyka, mówiąc inaczej, zachowań szkodzących zdrowiu. Dobrze byłoby też, aby zdrowie publiczne, a w tym promocja zdrowia, miały swojego rzecznika na szczeblu rządowym, wspierającego właściwy przebieg międzysektorowej instytucjonalizacji, tych przez wiele lat marginalizowanych dziedzin, a przy tym kluczowych dla zdrowia populacyjnego.

A teraz nieco na temat osób starszych. Jeśli rozważamy kwestie związane z promocją zdrowia osób starszych, nasuwają nam się przede wszystkim myśli o zapewnieniu ludziom starym życia w zdrowiu oraz wysokiej jego jakości. Ta koncentracja na osobach kieruje nas przede wszystkim ku edukacji, poradnictwu i społecznemu wsparciu. Trzeba jednak także pamiętać nie tylko o bezpośrednich narażeniach osób starszych. W dobie dynamicznego procesu starzenia się polskiej populacji uwagi wymagają także wyzwania stojące przed systemami społecznymi, stanowiącymi instytucjonalne ramy wszelkich działań dotyczących osób starszych. Dotychczas kolejne rządy kierowały oczekiwania związane z opieką nad osobami niepełnosprawnymi i starszymi przede wszystkim ku rodzinie. $Z$ racji rozpoczętych i dynamicznie rozwijających się procesów towarzyszących procesowi starzenia, takich na przykład jak proces zmniejszania się zasobów siły roboczej, znaczący spadek udziału osób młodych w populacji czy spadek liczebności polskiej populacji, dochodzi do obniżania się potencjału opiekuńczego rodzin. Stąd wyżej opisane podejście do rozwiązywania problemów opiekuńczych może w perspektywie nadchodzących lat zaowocować stopniową niewydolnością instytucji dedykowanych wspomaganiu bądź zastępowaniu rodziny $\mathrm{w}$ tym zakresie. Zgodnie $\mathrm{z}$ istniejącymi prognozami współczynnik obciążenia demograficznego osobami w wieku powyżej 65. roku życia zwiększy się trzykrotnie i w roku 2050 będzie wynosił 66 osób w wieku 65+ na 100 osób w wieku 15-64. Wraz z nasilaniem się procesu starzenia polskiej populacji należy także oczekiwać narastania liczby zachorowań, co oznacza rosnące obciążenie opieki zdrowotnej.

Jestem socjologiem, stąd jest całkowicie zrozumiałe, że patrzę na to, co mnie otacza, przede wszystkim z perspektywy tej właśnie dyscypliny nauki. Korzystając ze swoich socjologicznych obserwacji, chciałam zwrócić na koniec uwagę, że w wyniku upowszechnienia się idei postmodernizmu pojawił się bardzo szczególny rodzaj stosunku do starości, który można by określić mianem pewnego rodzaju obrzydzenia. W gonitwie za młodością i niezależnością nie chcemy pamiętać o starości, nie lubimy jej i zbyt często na co dzień odwracamy się od ludzi starszych, i to nie tylko rodzinnie czy towarzysko, ale i instytucjonalnie. Stąd myśląc także o procesie starzenia się polskiej populacji oraz malejącym potencjale opiekuńczym rodzin, powinno się podjąć działania mające na celu odbudowanie wartości, jaką jest starość, i przywrócenie jej właściwego miejsca $\mathrm{w}$ życiu społecznym.

MIROSŁAW WYSOCKI: Bardzo chciałem prosić teraz Pana prof. Tomasza Zdrojewskiego, żeby w syntetyczny sposób podsumował to, co zostało powiedziane.
TOMASZ ZDROJEWSKI: Szanowni Państwo! Sądzę, że najważniejszym wnioskiem i postulatem wyniesionym $z$ tej dyskusji jest to, abyśmy jako politycy i jako eksperci potrafili przekonać te osoby, które decydują o rozdziale środków publicznych, że promocja zdrowia to nie jest taka część systemu ochrony zdrowia jak ,muzyka lekka, łatwa i przyjemna", odwołując się do programów muzycznych Lucjana Kydryńskiego, które może niektórzy z Państwa pamiętają. To, co mówię, wynika nie tylko z poprawności społecznej i politycznej. Uważam, że promocja zdrowia to zagadnienie o poważnym ciężarze gatunkowym, jak symfonie Beethovena i opery Wagnera.

Promocja zdrowia dotyczy nie tylko młodej populacji, lecz także i starszej. Nawołują do tego strategie WHO i UE o potrzebie starzenia się w zdrowiu, gdy zasoby ochrony zdrowia (kadry i finanse) stają się coraz bardziej ograniczone. Ale co ważniejsze, istnieją dowody naukowe na skuteczność interwencji w zakresie promocji zdrowia i prewencji pierwotnej chorób przewlekłych. Odwołam się tu do wyników badań prowadzonych w instytucie. Pan prof. Bogdan Wojtyniak na wspomnianym już Forum Ekonomicznym w Krynicy przedstawił opublikowany w „British Medical Journal” artykuł na ten temat.

Naszą rolą jest przekonać tych kilka ważnych osób w państwie do tego, że nie należy unikać inwestycji w promocję zdrowia, obawiając się marnotrawstwa środków. Argumentem są dowody naukowe i dobre praktyki, aby nie można było odrzucać programów inwestowania w zdrowie we wszystkich fazach ludzkiego życia i ,w różnych politykach”.

Chciałbym postulować, żeby najważniejszym zadaniem dla Pana ministra i parlamentarzystów, wyniesionym $\mathrm{z}$ tej konferencji, było przekonanie innych policy makers o doinwestowaniu w zdrowie, przy czym należy wspierać mądrze działania profesjonalne - jak powiedziała Pani prof. Stanisława Golinowska - oparte na wynikach badań, na najlepszych przykładach w Europie i na świecie. Do tego między innymi potrzebujemy dobrych danych. Stąd gorąca prośba do Pana ministra, żeby spróbował uruchomić program PolSenior2. Jeśli będziemy mieli dobre dane o sytuacji zdrowotnej i społecznej starszych Polaków, to ten polski program Komisji Europejskiej, który dzisiaj mamy dzięki Pani prof. Stanisławie Golinowskiej, będzie miał dodatkowe dane do tworzenia modeli o różnych zależnościach i do przekonywania finansistów i Ministerstwa Finansów, że warto to robić.

Pan prof. Mirosław Wysocki prosił o puentę - to jest właśnie moja puenta do tej dyskusji, z której się bardzo dużo dowiedziałem: przede wszystkim o wartości działań oddolnych (u podstaw) w samorządach lokalnych. Bardzo serdecznie dziękuję za dyskusję, w której miałem zaszczyt i przyjemność uczestniczyć.

Jako że Pani prof. Stanisława Golinowska nie uczestniczyła w tej dyskusji, a prace w projekcie „ProHealth $65+$ " pozwalają na komentarz z perspektywy doświadczeń innych krajów, to zapowiadam jej głos w materiałach pokonferencyjnych.

BEATA MAŁECKA-LIBERA: Chciałam coś dodać na zakończenie. To się zrodziło ad hoc. Prowadzę Ze- 
spół Zdrowia Publicznego w Sejmie. Myślę, że promocja zdrowia to byłby dobry temat. Jestem do dyspozycji, możemy za chwilę porozmawiać o tym, aby zorganizować taką debatę w szerszym gronie parlamentarzystów.

STANISŁAWA GOLINOWSKA: Ustawy o zdrowiu publicznym powstawały w wielu krajach już pod koniec XIX i na początku XX wieku, także w Polsce. To były ustawy tradycyjnie definiowanego zdrowia publicznego, higieny i przeciwdziałania ryzyku chorób zakaźnych, zgodnie z wyzwaniami epidemiologicznymi tamtej epoki. Bardziej nowoczesne w treści ustawy o zdrowiu publicznym, uwzględniające promocję zdrowia, zaczęły powstawać dopiero po słynnej konferencji w Ottawie, na której sformułowano Kartę Promocji Zdrowia.

Na początku XXI wieku w wielu krajach uchwalono nowe ustawy o zdrowiu publicznym. Stanowią one odpowiedź na wyzwania epidemiologiczne, demograficzne i społeczne naszych czasów. Obejmują w szerokim zakresie promocję zdrowia i prewencję chorób przewlekłych, akcentując społeczne i środowiskowe determinanty zdrowia. Takie ustawy uchwalono we Francji (2004), w Holandii (2008), Szwajcarii (2009), Finlandii (2010), w Wielkiej Brytanii (2010, Public health vision - Healthy lives, healthy people) i w Norwegii (2012). Najnowsze ustawy obejmują oprócz prewencji także zagadnienia opieki, na przykład ustawa brytyjska (2013) i niemiecka (2015).

Doświadczenia regulacyjne dotyczące zdrowia publicznego w wielu krajach dowodzą, że ustawy mają istotne znaczenie dla uruchomienia odpowiednich procesów na rzecz ochrony zdrowia populacji. Ustawy definiują cel i ukazują jego zakres oraz strukturę przedmiotową. Wskazują także odpowiednie narzędzia realizacji celu. Chodzi przede wszystkim o zasoby: instytucje, kadry i środki finansowe, niezbędne do uruchomienia realnego procesu.

Nawet najlepiej przygotowana i zapisana ustawa jest jednak niewystarczająca, gdy poprzestaje się na jej uchwaleniu. Uruchomienie realnego procesu wymaga przepisów wykonawczych. W polskiej tradycji tworzenia ustaw mamy wiele znakomicie napisanych dokumentów prawniczych, które są nierealizowane, ponieważ nie pociągają za sobą regulacji i działań wykonawczych.

Polska ustawa o zdrowiu publicznym z 2015 roku była dokumentem długo oczekiwanym. Gdy już została uchwalona, to z jednej strony wyrażono ulgę, że wreszcie jest, ale $z$ drugiej - zakłopotanie, ponieważ zawiera niewiele działań nowych i mobilizujących do wdrożenia. W ustawie zbiera się działania, w gruncie rzeczy już wcześniej ustalone i realizowane, a tylko hasłowo dopisuje kilka nowych, na przykład o promocji zdrowia, co w nowoczesnym zdrowiu publicznym jest jej fundamentem. W tej sprawie odwołuje się wprawdzie do Narodowego Programu Zdrowia, ale nie formułuje kompleksowo kierunków zasadniczych. Jednak najsłabszym punktem ustawy jest to, że nie wskazuje zasobów niezbędnych do realizacji: kto ma ją realizować (jakie zawody i stanowiska), w jakich instytucjach i za pomocą jakich mechanizmów i środków.

Polska ustawa o zdrowiu publicznym z 2015 roku dołączyła do grona nowoczesnych ustaw o zdrowiu publicznym, ale wymagałaby, moim zdaniem, jeśli nie rozszerzającej i konkretyzującej nowelizacji, to odpowiednich przepisów wykonawczych.

Wypowiedzi spisała i przygotowała do publikacji (po ich autoryzacji) Elżbieta Ryś.

Redakcja: Stanisława Golinowska

Adres do korespondencji: Stanisława Golinowska, Zakłada Ekonomiki Zdrowia i Zabezpieczenia Społecznego, Instytut Zdrowia Publicznego, Wydział Nauk o Zdrowiu, Uniwersytet Jagielloński Collegium Medicum, ul. Grzegórzecka 20,31-531 Kraków, stellag@onet.pl 